\title{
OCHRATOXIN A LEVELS IN FOOD AND BEVERAGE SAMPLES FROM TURKEY
}

\author{
I. GAZIOGLU $U^{\mathrm{a}}$ and U. KOLAK ${ }^{\text {b* }}$ \\ ${ }^{a}$ Department of Analytical Chemistry, Faculty of Pharmacy, Bezmialem Vakif University, 34093 Istanbul. Turkey \\ bepartment of General and Analytical Chemistry, Faculty of Pharmacy, Istanbul University, 34116 Istanbul. \\ Turkey
}

(Received: 6 July 2017; accepted: 2 November 2017)

The current work reports the ochratoxin A (OTA) levels in 23 food (bread, dried fruit, pulse) and beverage (black tea, coffee) products commonly consumed in Turkey determined with ELISA. OTA levels in kidney bean, haricot bean, and red lentil samples from Turkey were investigated for the first time in this study. The highest OTA levels were detected in instant coffee $\left(158.9 \mu \mathrm{g} \mathrm{kg}^{-1}\right)$, black tea $\left(139.5 \mu \mathrm{g} \mathrm{kg}{ }^{-1}\right)$, and filter coffee $\left(118.4 \mu \mathrm{g} \mathrm{kg}^{-1}\right) \mathrm{samples}$. Of the tested samples, $78.27 \%$ exceeded legal limits of OTA. These results support the existing knowledge that food and beverages should be regularly and effectively controlled to protect human health.

Keywords: ochratoxin A, ELISA, bread, dried fruit, black tea, coffee

Aflatoxins, ochratoxins, deoxynivalenol, and zearalenone are the most frequent mycotoxins found in plants and in their by-products pre- or post-harvest, during preparation and storage, and they exhibit a potential risk to organisms (MilićEvić et al., 2010).

Ochratoxin A (OTA) is produced by Aspergillus ochraceus, A. westerdijkiae, $A$. alliaceus, A. sclerotiorum, A. fresenii, A. albertensis, Penicillium verrucosum, $P$. nordicum, $P$. chrysogenum, P. glycyrrhizacola and P. polonicum, and it is of the most toxic effects among all ochratoxins. OTA can be of nephrotoxic, hepatotoxic, teratogenic, mutagenic, carcinogenic, fertility inhibition effects with immuno-suppressive nature to a variety of laboratory animals (WANG et al., 2016). OTA was classified by IARC (International Agency for Research on Cancer) as a possible carcinogen for humans (Group 2B) (TURNER et al., 2009). OTA has been commonly found in cereals, starch rich foods with spices, coffee, dried fruit, grape, wine, beer, and meat (ASSAF et al., 2004). Researchers reported that food has been mainly contaminated with OTA during storage (Moss, 1996; YANG et al., 2014), and it is stable during most food processing stages (COPETTI et al., 2010). Also, roasting conditions, like roasting time, may play a partial role in the OTA reduction during coffee roasting (VAN DER STEgen et al., 2001).

Nowadays, food control has been carried out regularly in many countries to protect human and animal health. The European Union and Turkish Codex established a maximum level of $5 \mu \mathrm{g} \mathrm{kg}^{-1}$ for OTA in coffee and pulses, $3 \mu \mathrm{g} \mathrm{kg}^{-1}$ for OTA in bread, and $10 \mu \mathrm{g} \mathrm{kg}^{-1}$ for OTA in dried fruit (EC, 2006; TURKISH FoOd CODEX, 2011). Different methods have been used for the analysis of mycotoxins, and ELISA (enzyme-linked immunosorbent assay), being one of them, is a simple, specific, sensitive, low-cost, and rapid screening method (TURNER et al., 2009).

\footnotetext{
* To whom correspondence should be addressed. Phone: +90 212 4400258; fax: +90 212 4400254; e-mail: kolak@istanbul.edu.tr
} 
The aim of the present study was to evaluate the presence of OTA in 14 food and 9 beverage samples of bread, dried fruit, pulse, black tea, and coffee from Turkey using ELISA. Bread, dried fruit, and pulse are important constituents of the diet of Turkish people, who consume approximately 7.85 million tons of bread, 30000 tons of dried fruit, and 350000 tons of pulse per year (Republic of Turkey Ministry of Health, 2010). China, India, Kenya, Sri Lanka, and Turkey are the largest tea producers in the world (FAO, 2015). The consumption of black tea is more than 215000 tons per year in Turkey. During the whole day, Turkish people drink traditional Turkish tea, which is made with a special technique, and they usually offer traditional tea to guests to demonstrate their hospitality (KILIC et al., 2012). Another important beverage in Turkish culture is coffee, especially Turkish coffee. Since the consumption of the mentioned foods and beverages is very high in Turkey, their OTA level was studied in the current work.

\section{Materials and methods}

\subsection{Chemicals and instrumentation}

Methanol was supplied from Merck (Darmstadt, Germany), ELISA was performed using the Ridascreen Fast Ochratoxin A (Art No: R5402) (R-Biopharm, Darmstadt, Germany). Ochratoxin A was purchased from R-Biopharm. All solvents were of analytical grade. Spectrophotometric analyses were performed by BioTek Power Wave XS (BioTek, USA).

\subsection{Safety precautions}

OTA is a toxic substance. They were always manipulated in solution, avoiding the formation of dust and aerosols. Nitrile gloves were used for all procedures.

\subsection{Samples}

Twenty-three food samples were randomly purchased from different supermarkets in Istanbul (Turkey) in 2012. All samples (25-50 g) were kept in suitable containers and stored at $+4{ }^{\circ} \mathrm{C}$ until initial sample preparation, then at $-20{ }^{\circ} \mathrm{C}$ until analysis. A representative sample was ground and thoroughly mixed for the extraction procedure.

\subsection{Sample preparation}

Five grams of ground sample was weighed into a suitable container and $12.5 \mathrm{ml}$ of methanol (70\%) was added for ochratoxin A determination. After shaking vigorously for 3 min with a blender (Waring, 8011.S), the extract was filtered through Whatman No. 1 filter. One millilitre of the obtained filtrate was diluted with $1 \mathrm{ml}$ of distilled water. Fifty microlitres of the diluted filtrate was used per well in the test.

\subsection{Procedure for ochratoxin A determination}

Fifty microlitres of standard or prepared sample was transferred into separate wells. First, enzyme conjugate and then ochratoxin A antibody solution ( $50 \mu \mathrm{l}$ of each one) were added to each well. After mixing gently by shaking the plate manually and incubating at room temperature for $10 \mathrm{~min}$, the liquid was removed from the wells. The wells were filled with distilled water and evacuated again and then all remaining liquid was removed. The washing 
step was repeated two more times. Then, $100 \mu \mathrm{l}$ of substrate/chromogen was added to each well. The plate was mixed gently by shaking manually and incubated at room temperature in the dark for 5 min. Finally, $100 \mu$ of stop solution was added to each well and mixed gently by shaking manually. The absorbance was measured at $450 \mathrm{~nm}$. A special software, RIDA ${ }^{\circledR}$ SOFT Win (Art. No. Z9999), was used for the evaluation of Ridascreen ${ }^{\circledR}$ enzyme immunoassays. LOD indicated by Ridascreen ELISA kits is $5 \mu \mathrm{g} \mathrm{kg}{ }^{-1}$ for ochratoxin A (R-BiOPHARM, 2006).

\subsection{Analytical quality assurance}

Analyses were performed with the R-Biopharm ELISA system (Darmstadt, Germany), which is accredited by DQS (the German Accreditation body) to ISO 9001, 13485, and 17025. To perform a recovery study, $5 \mathrm{~g}$ of toxin-free samples were used. Stock solutions of OTA $\left(100 \mu \mathrm{g} \mathrm{kg}^{-1}\right)$ were prepared in methanol-water (40:60) and stored at $-36{ }^{\circ} \mathrm{C}$. OTA at two levels $\left(8,15 \mu \mathrm{g} \mathrm{kg}^{-1}\right)$ was spiked to each sample (Table 1).

Table 1. Recovery percentage of OTA in food samples. 2 toxin-free samples were used for this purpose. $\mathrm{LOD}<5 \mu \mathrm{g} \mathrm{kg}^{-1}$ as indicated by R-Biopharm test kits

\begin{tabular}{|c|c|c|c|c|c|c|}
\hline \multicolumn{7}{|c|}{ Recovery (Spiked level: $15 \mu \mathrm{g} \mathrm{kg}^{-1}$ ) } \\
\hline & 1. analysis & 2. analysis & Mean value & $\begin{array}{l}\text { Standard } \\
\text { deviation }\end{array}$ & RSDr (\%) & Recovery (\%) \\
\hline Bread & 14.14 & 13.87 & 14.01 & 0.19 & 1.38 & 93.38 \\
\hline Dried fruit & 13.56 & 12.85 & 13.21 & 0.50 & 3.81 & 88.04 \\
\hline Pulse & 13.35 & 13.95 & 13.65 & 0.42 & 3.10 & 91.02 \\
\hline Tea & 15.04 & 14.39 & 14.72 & 0.46 & 3.13 & 98.11 \\
\hline Coffee & 14.70 & 14.28 & 14.49 & 0.30 & 2.05 & 96.61 \\
\hline \multicolumn{7}{|c|}{ Recovery (Spiked level: $8 \mu \mathrm{g} \mathrm{kg}^{-1}$ ) } \\
\hline & 1. analysis & 2. analysis & Mean value & $\begin{array}{l}\text { Standard } \\
\text { deviation }\end{array}$ & RSDr (\%) & Recovery (\%) \\
\hline Bread & 8.33 & 7.90 & 8.11 & 0.30 & 3.71 & 101.40 \\
\hline Dried fruit & 8.66 & 7.91 & 8.28 & 0.53 & 6.39 & 103.53 \\
\hline Pulse & 8.76 & 7.21 & 7.99 & 1.10 & 13.77 & 99.82 \\
\hline Tea & 8.38 & 7.15 & 7.76 & 0.87 & 11.18 & 97.05 \\
\hline Coffee & 8.14 & 7.69 & 7.92 & 0.32 & 4.03 & 98.96 \\
\hline
\end{tabular}

\section{Results and discussion}

In this study, bread (toasted multigrain, organic wheat, light wheat, toasted, household bread), dried fruit (prune, apricot, black raisin, raisin), pulse (chickpea, haricot bean, kidney bean, red lentils, green lentils), black tea, and coffee (filter, instant, instant without sugar, 25 min roasted, $22 \mathrm{~min}$ roasted, $20 \mathrm{~min}$ roasted, $12 \mathrm{~min}$ roasted, coffee bean) were investigated using ELISA to determine their OTA levels.

Toasted multigrain, organic wheat, light wheat, and toasted breads contained OTA above the EU limit of $3 \mu \mathrm{g} \mathrm{kg}^{-1}$ (between 5.94-11.34 $\mu \mathrm{g} \mathrm{kg}^{-1}$ ), OTA was not detected in household 
bread (Table 2). Health benefits of bread and wheat products play an important role in the human diet. Nowadays, researchers suggest that eating white bread could benefit health by increasing the number of beneficial gut bacteria (CUERVo et al., 2014). When cereals are consumed with pulses, the protein quality automatically improves due to mutual supplementation. PIEMONTESE and co-workers (2017) developed a new extraction media for determination of OTA in wheat. They analysed the bread crumb samples purchased at local retails in Italy, and they detected the OTA level as $2.15 \mu \mathrm{g} \mathrm{kg}^{-1}$. In another study, 160 samples of fresh wheat bread and rice from Turkey were analysed to detect OTA. OTA levels of wheat bread and rice samples did not exceed the EU limit of $3 \mu \mathrm{g} \mathrm{kg}^{-1}$ (GolgE \& KABAK, 2016). PAIGA and co-workers (2013) purchased 64 bread samples (wheat bread, maize bread, and traditional "broa de Avintes" (half maize and half rye composition)) from markets, bakeries, and hypermarkets in Portugal. They found that OTA level in the analysed samples was depending on bread type. OTA was detected in $72 \%$ of the samples with a maximum value of $0.27 \mathrm{ng} \mathrm{g}^{-1}$. In their study, none of the samples exceeded the legal European limit of $3 \mu \mathrm{g} \mathrm{kg}^{-1}$ for cereal based products. But, OTA levels were found to be high in maize-based breads.

Table 2. Ochratoxin A concentration ranges in the samples

\begin{tabular}{|c|c|c|c|}
\hline \multirow[t]{2}{*}{ Sample matrix } & \multicolumn{3}{|c|}{ Number of samples contaminated with OTA in the range $\mu \mathrm{g} \mathrm{kg}^{-1}$} \\
\hline & $<$ LOD $^{*}$ & $5.0-15.0$ & $>15.0$ \\
\hline Bread & 1 & 4 & - \\
\hline Dried fruit & - & - & 4 \\
\hline Pulse & 3 & - & 2 \\
\hline Tea & - & - & 1 \\
\hline Instant coffee & - & - & 2 \\
\hline Roasted coffee & - & 1 & 3 \\
\hline Coffee bean & 1 & - & - \\
\hline
\end{tabular}

*LOD $<5 \mu \mathrm{g} \mathrm{kg}^{-1}$ for ochratoxin A, indicated by R-Biopharm test kits.

In Turkey, fruits are dried in the sun, and are commonly consumed by Turkish people. All around the world, $75 \%$ of dried apricots are produced in Turkey (UNAL, 2010). In this study, OTA level of the analysed dried apricot sample was found to be 43.57 $\mu \mathrm{g} \mathrm{kg}{ }^{-1}$. AzAIEZ and co-workers (2015) reported that 27 dried apricot samples, which were purchased from Tunisian and Spanish markets, were not contaminated with OTA. On the other hand, 6 other mycotoxins were detected in the analysed dried apricot samples. BIRCAN (2009) analysed 20 samples of dried apricots from Turkey, and only one sample was found to be contaminated with OTA $\left(0.97 \mu \mathrm{g} \mathrm{kg}^{-1}\right)$.

In this study, OTA contamination was found to be $16.99,22.60$, and $49.30 \mu \mathrm{g} \mathrm{kg}^{-1}$ in dried prune, black raisin, and raisin, respectively. AsGHAR and co-workers (2016) investigated 170 samples of export quality raisins in Pakistan. About $72 \%$ of the samples were contaminated with OTA, ranging $0.14-12.75 \mu \mathrm{g} \mathrm{kg}^{-1}$. However, in $95.3 \%$ of the tested samples, OTA level was lower than the maximum limits regulated by the EU. In a similar study from Turkey, MEYVACI and co-workers (2005) analysed 264 crude sultana samples collected between 1998 and 2000 annually from vineyards and from packing-houses. The analysis of crude sultanas 
revealed that $32.2 \%$ of the samples contained no detectable OTA, whereas $9.8 \%$ of sultana samples had OTA concentrations above $10 \mathrm{mg} \mathrm{kg}^{-1}$, and OTA levels of the remaining samples were within the range $0.026-10 \mathrm{mg} \mathrm{kg}^{-1}$. Among the analysed samples, the highest level of OTA was detected as $54 \mathrm{mg} \mathrm{kg}^{-1}$.

Chickpea, haricot bean, kidney bean, red lentils, and green lentils have been commonly consumed in Turkey. OTA levels in kidney bean, haricot bean, and red lentil samples were determined for the first time in this study, and no toxin was detected in chickpea, haricot bean, and green lentils samples. However, $39.74 \mu \mathrm{g} \mathrm{kg}^{-1}$ OTA was found in kidney bean samples. BeHEShti and AsAdi (2013) analysed samples that consisted of 15 samples of chickpea, 20 samples of green lentils, and 40 samples of wheat flour from Iran. OTA was detected in $13.3 \%$ of chickpea, $10 \%$ of green lentil samples. All contaminated samples had an OTA level below the legal limit of OTA according to the European Union and Iranian National Standards.

In this study, OTA was detected in $78.26 \%$ of beverage samples, the highest concentration was found in instant coffee sample $\left(158.90 \mu \mathrm{g} \mathrm{kg}^{-1}\right)$. Black tea $(139.54$ $\left.\mu \mathrm{g} \mathrm{kg}^{-1}\right)$, filter coffee $\left(118.37 \mu \mathrm{g} \mathrm{kg}^{-1}\right)$, and instant coffee without sugar $\left(16.93 \mu \mathrm{g} \mathrm{kg}^{-1}\right)$ were also contaminated with OTA. Twelve minutes roasted coffee $\left(9.23 \mu \mathrm{g} \mathrm{kg}^{-1}\right)$ and coffee bean $\left(3.98 \mu \mathrm{g} \mathrm{kg}^{-1}\right)$ samples had OTA below legal limits. In a study from Germany, it was stated that no toxin had been found in black and fruit tea samples (detection limit in tea leaves is 0.3 $\mu \mathrm{g} \mathrm{kg}^{-1}$ ). In the same study, they found that $50 \%$ of the samples of roasted and ground coffee, with and without caffeine, contained OTA at concentrations of $0.3-6.3 \mu \mathrm{g} \mathrm{kg}^{-1}$, and approximately $90 \%$ of instant coffee samples with caffeine contained the toxin in the range of 0.3-9.47 $\mu \mathrm{g} \mathrm{kg}^{-1}$ (BREsCH et al., 2000). In another study, TARAdOLSIRITHITIKUL and coworkers (2017) analysed 200 samples of the naturally contaminated green coffee bean by using HPLC to determine their OTA concentrations, and they found that OTA concentration ranged from 0 to $1.90 \mu \mathrm{g} \mathrm{kg}{ }^{-1}$.

\section{Conclusions}

Food controls are necessary for providing safe and healthy food. In the present study, some of the most consumed foods and drinks in Turkey were analysed to detect their OTA levels, and it was found that $21.73 \%$ of the analysed samples were not contaminated with OTA, the highest level of OTA was detected in instant coffee sample. This study supports that food and beverages should be checked for OTA to protect human health.

This work was supported by the Research Fund of Istanbul University (Project number: BYP 19795).

\section{References}

Asghar, M.A., Ahmed, A. \& Iqbal, J. (2016): Aflatoxins and ochratoxin A in export quality raisins collected from different areas of Pakistan. Food Addit. Contam. B., 9(1), 51-58.

Assaf, H., Betbeder, A.M., Creppy, E.E., Pallardy, M. \& Azouri, H. (2004): Ochratoxin A levels in human plasma and foods in Lebanon. Hum. Exp. Toxicol., 23(10), 495-501.

Azaiez, I., Font, G., Manes, J. \& Fernandez-Franzon, M. (2015): Survey of mycotoxins in dates and dried fruits from Tunisian and Spanish markets. Food Control, 5, 340-346. 
Beheshti, H.R. \& Asadi, M. (2013): Ochratoxin A in several grains in Iran. Food Addit. Contam. B, 6(3), $200-202$. BirCAN, C. (2009): Incidence of ochratoxin A in dried fruits and co-occurrence with aflatoxins in dried figs. Food Chem. Toxicol., 47(8), 1996-2001.

Bresch, H., Urbanek, M. \& Hell, K. (2000): Ochratoxin A in coffee, tea and beer. Arch. Lebensmittelhyg., 51(4-5), 89-94.

Copetti, M.V., Pereira, J.L., Iamanaka, B.T., Pitt, J.I. \& Taniwaki, M.H. (2010): Ochratoxigenic fungi and ochratoxin A in cocoa during farm processing. Int. J. Food Microbiol., 143(1-2), 67-70.

Cuervo, A., Valdés, L., Salazar, N., Reyes-Gavilán, C.G.D.L., Ruas-Madiedo, P., Gueimonde, M. \& González, S. (2014): Pilot study of diet and microbiota: Interactive associations of fibers and polyphenols with human intestinal bacteria. J. Agr. Food Chem., 62, 5330-5336.

EC (2006): Commission Regulation (EC) N 1881/2006 of 19 December 2006 setting maximum levels for certain contaminants in foodstuffs. OJ of the $E U, 364,5 \mathrm{e} 24$.

FAO (2015): World tea production and trade current and future development, Rome. 17 pages.

Golge, O. \& KaBAK, B. (2016): First report: Exposure estimates to ochratoxin A through wheat bread and rice intake in Turkey. J. Cereal Sci., 69, 213-217.

Kilic, O., Gunduz, O., Eryilmaz, G.A. \& Emir, M. (2012): Çay tüketiminde tüketici davranişlarinin belirlenmesi: Samsun ili örneği (Determination of the consumer behaviour in tea consumption: the case of Samsun province). Harran Tartm ve Gida Bilimleri Dergisi, 16(4), 19-25.

Meyvaci, K.B., Altindisli, A., Aksoy, U., Eltem, R., Turgut, H., Arasiler, Z. \& Kartal, N. (2005): Ochratoxin A in sultanas from Turkey I: Survey of unprocessed sultanas from vineyards and packing-houses. Food Addit. Contam., 22, 1138-1143.

MilićEvić, D.R., ŠKrinjar, M. \& Baltić, T. (2010): Real and perceived risks for mycotoxin contamination in foods and feeds: Challenges for food safety control. Toxins (Basel), 2(4), 572-592.

Moss, M.O. (1996): Mode of formation of ochratoxin A. Food Addit. Contam., 13, 5-9.

Paiga, P., Morais, S., Oliva-Teles, T., Correia, M., Delerue-Matos, C., Sousa, A.M.M., Goncalves, M.D., Duarte, S.C., Pena, A. \& Lino, C.M. (2013): Determination of ochratoxin A in bread: Evaluation of microwaveassisted extraction using an orthogonal composite design coupled with response surface methodology. Food Bioprocess. Tech., 6, 2466-2477.

Piemontese, L., Perna, F.M., Logrieco, A., Capriati, V. \& Solfrizzo, M. (2017): Deep eutectic solvents as novel and effective extraction media for quantitative determination of ochratoxin $\mathrm{A}$ in wheat and derived products. Molecules, 22(1), 121 (9 pages)

R-Biopharm (2006): Enzyme immunoassay for the quantitative analysis of ochratoxin A Art. No. R5402, Darmstadt, Germany.

Republic of Turkey Ministry of HeAlth (2010): Türkiye beslenme ve sağllk araştırmasl, beslenme durumu ve alışkanlıklarının değerlendirilmesi: sonuç raporu (Turkey nutrition and health survey, evaluation of nutrition status and habits: Final report). T.C. Sağlık Bakanlığı Yayın No: 93, Sağlık Araştırmaları Genel Müdürlüğü Yayın No: SB-SAG-2014/0.

Taradolsirithitikul, P., Sirisomboon, P. \& Sirisomboon, C.D. (2017): Qualitative and quantitative analysis of ochratoxin A contamination in green coffee beans using Fourier transform near infrared spectroscopy. J. Sci. Food Agr., 97, 1260-1266.

TuRkish Food Codex (2011): Turkish food codex legislation of food contaminants. Official Gazette of Turkish Republic, 29.12.2011-28157; Legislation Number: 5996. Prime Ministry Press, Ankara, Turkey.

Turner, N.W., Subrahmanyam, S. \& Piletsky, S.A. (2009): Analytical methods for determination of mycotoxins: A review. Anal. Chim. Acta, 632(2), 168-180.

Unal, M.R. (2010): Fırat Kalkınma Ajansı, Kayısı araştırma raporu (Firat Development Agency, Apricot research report. Malatya (http://www.fka.org.tr), last accessed 2 November 2017, 63 pages.

Van der Stegen, G.H., Essens, P.J. \& VAn der Lijn, J. (2001): Effect of roasting conditions on reduction of ochratoxin A in coffee. J. Agr. Food Chem., 49(10), 4713-4715.

Wang ,Y., Wang, L., Liu, F., Wang, Q., Selvaraj, J. N., Xing, F., Zhao, Y. \& Liu, Y. (2016): Ochratoxin A producing fungi, biosynthetic pathway and regulatory mechanisms. Toxins (Basel), 8(3), 83-98.

Yang, J.Y., Li, J., Jiang, Y.M., Duan, X.W., Qu, H.X., Yang, B., Chen, F. \& Sivakumar, D. (2014): Natural occurrence, analysis, and prevention of mycotoxins in fruits and their processed products. Crit. Rev. Food Sci., $54(1), 64-83$. 